\title{
Complexity in Promoting a Teaching to Develop Creativity of Gifted Students: Contributions from Morin and Jung
}

\section{Fernanda Hellen Ribeiro Piske1, Tania Stoltz ${ }^{1}$, Ettiène Guérios¹, Denise de Camargo², Samarah Perszel de Freitas ${ }^{3}$, Carmen Lúcia Dias ${ }^{4}$}

${ }^{1}$ Federal University of Paraná, Curitiba, Brazil

${ }^{2}$ Tuiuti University, Curitiba, Brazil

${ }^{3}$ Positivo University, Curitiba, Brazil

${ }^{4}$ University of Oeste Paulista, Presidente Prudente, Paulista, Brazil

Email: nandahellen@hotmail.com

How to cite this paper: Piske, F. H. R., Stoltz, T., Guérios, E., de Camargo, D., de Freitas, S. P., \& Dias, C. L. (2017). Complexity in Promoting a Teaching to Develop Creativity of Gifted Students: Contributions from Morin and Jung. Creative Education, 8, 925-934.

https://doi.org/10.4236/ce.2017.86067

Received: December 14, 2016

Accepted: May 24, 2017

Published: May 27, 2017

Copyright () 2017 by authors and Scientific Research Publishing Inc. This work is licensed under the Creative Commons Attribution International License (CC BY 4.0).

http://creativecommons.org/licenses/by/4.0/ cC) (i) Open Access

\begin{abstract}
This research aims to contribute to the reflection of the teaching staff about the complexity in attending gifted students. For Jung and Morin complex things are characterized by uncertainty and not as clarity and response. Although not specifically mention gifted students in their works, Jung and Morin highlight the complexity in various contexts. Jung's analytical psychology and Morin's complexity theory are important to understand how complex it can be to teach gifted students. For Morin and Jung, the teaching staff has a key role in making their students become independent and investigative individuals. So the desire to investigate about the area of interest of the gifted child will depend on how this child is encouraged by their teachers. Advancement during the teaching-learning process does not depend exclusively on the method, but also on making the child aware that he/she can develop individually within a collective education. In the case of the gifted child, the intervention of the teaching staff is fundamental to develop their high abilities through the development of their creativity in the interaction with their peers.
\end{abstract}

\section{Keywords}

Edgar Morin, Carl Jung, Teaching Staff, Gifted Students

\section{Introduction}

Teaching a gifted student can be something complex. The complexity in performing educational practices for this demand is noted by teachers who do not always know how to stimulate the creativity of these children. In this sense, this 
research aims to contribute to the reflection of the teaching staff about the complexity in attending gifted students.

The complexity makes us think about the problem of incompleteness of knowledge generating a reflection of how to respond to complex issues in education. It is elucidated that complexity arises as difficulty, as uncertainty and not as clarity and response. "The problem is to know if there is a chance to respond to the challenge of uncertainty and difficulty." (Morin, 2014: 177).

Jung (2007) explains that the term complex can be related to unconscious, repressed, yet highly influential symbolic material that is incompatible with the consciousness. Something complex can be defined as a gathering of images and ideas, conglomerated around a core derived from one or more archetypes, and characterized by a common emotional tonality. Jung (1953) points out four major archetypes, but also believed that there was no limit to the number that may exist.

Jung (1947) named his theory as complex theory. The author himself acknowledged the high level of complexity of his work. The archetypes are important in Jung's theory; it is important to understand how this author defines them.

Here, there are some explanations about four major archetypes "Self, Shadow, Anima and Persona" of Jung:

Regarding the self, Jung (1921) explains that it is an archetype that symbolizes the unified unconsciousness and consciousness of a person. Self occurs through a process known as individuation, in which the various aspects of personality are integrated. The self was represented by Jung (1953) as a circle, square, or mandala.

Jung (1948) defined the shadow as an archetype that consists of the sex and life instincts. The shadow shows part of the unconscious mind and is composed of repressed ideas, weaknesses, desires, instincts and shortcomings.

Jung (1947) nominated the anima as a feminine image in the male psyche, and the animus is a male image in the female psyche. The anima/animus can represent the true self rather than the image we present to others and serves as the primary source of communication with the collective unconscious.

Jung (1948) designated the persona as how we present ourselves to the world. The persona denoted all of the different social masks that we wear among various groups and situations. It acts to shield the ego from negative images. According to Jung, the persona may appear in dreams and take different forms (Jung, 1921, 1947, 1948, 1953).

For Jung and Morin complex things are characterized by uncertainty. Although not specifically mention gifted students in their works, Jung and Morin highlight the complexity in various contexts. Jung's analytical psychology and Morin's complexity theory are important to understand how complex it can be to teach gifted students. From this point we should think about the importance of teacher training for all levels of schooling, considering the multi-conditioning factors that only belong to them and determining them, as well as the complexity 
of the constitutive mesh of pedagogical practice (Guérios, 2002). It should be considered that in the case of teaching gifted students, understand their way of perceiving the world and their complex thinking in solving problems means a challenge for many teachers. If during teaching there is an incentive to multidimensional knowledge, it would probably be easier to understand complex thinking. "In fact, the aspiration to complexity tends towards multidimensional knowledge." (Morin, 2014: 177).

A fundamental aspect to overcome this challenge is to understand how teachers understand the school space. Guérios $(2002,2005)$ identified in their researches that, depending on how they understand it and how they conceive pedagogical practice, Teachers may be repeating mechanical and fragmented practices by curtailing the creativity of students, or on the contrary, creating possibilities that stimulate cognitive development and lay roots for the development of the complex thinking of students, and in particular of gifted students. To that end, teachers 'action must be dynamic in that, according to Guérios, "imagination and creativity surpass and transcend the limits imposed by the walls of the classroom, the teachers' room, and pedagogical coordinations" (2005, p. 141).

Morin (2000a, 2000b, 2007) explains that complexity thinking is animated by a permanent tension between the pursuit of "a knowledge that is neither fragmented nor compartmentalized, and the recognition of the incompletion and incompleteness of any knowledge" (Morin 2000a: 18).

Knowledge about the needs of gifted students is complex and challenging. To understand these needs require an analysis of these students, despite having high abilities, they may have difficulties that are not always apparent. Morin (1977, $1979,1980)$ understands the human being in multidimensional perspective. Morin (2000b: 38) explains that "complex units such as human being or society, are multidimensional: in this way, the human being is at the same time biological, psychological, social, emotional and rational and not perceived directly".

Morin (1996) explains that the construction of knowledge is from self-knowledge, to reach an awareness of the reality that surrounds it. For Morin (1996) autonomy is gained from numerous dependencies, for example, we must learn to speak and write, we need to be loved and created by parents. Thus, autonomy cannot be understood as opposed to dependence, but complementary (Morin, 1996).

According to Jung (1983) self consciousness is the most important thing to know what you really want. In this sense, self-knowledge is essential to feel free and to become a human being conscious of himself/herself. For Jung:

What matters is not the degree of knowledge that the student finishes the course, but if the school make the student feel free or not, as a human being conscious of himself. Without this self-awareness, somebody will never know what he/she truly wants and he/she will always remain dependent on others and he/she will only try to imitate others by experiencing the feeling of being unknown and oppressed by others (Jung, 1983: 60).

According to Morin and Jung, students' autonomy and self-knowledge are 
fundamental aspects for these individuals have a full development, so it is up to the teaching staff promote a teaching with freedom of expression and the encouragement of creativity.

This manuscript is organized in two sections where aspects of complexity and creativity will be treated as important and constitutive elements of knowledge, which may provide multiple possibilities for the understanding of complex thinking and which should be widely developed at school.

Some activities, such as curricular enrichment, are presented and can be considered as parameters for the school to take initiatives to include creative work with the gifted child in some areas of knowledge.

In conclusion, Morin and Jung point out the key role of teaching staff in making their students independent and investigative individuals. Thus, the desire to investigate the area of interest of the gifted child will depend on how that child is encouraged by their teachers. In such a way, their intervention is fundamental to develop the high capacities of their gifted students through the development of their creativity in the interaction with their peers.

\section{The Importance of Creativity}

It is essential to have a teaching that values multidimensional knowledge in which there are several possibilities to understand the specificities of the students. Through this bias, working with creativity can provide multiple possibilities for understanding complex thinking.

Regarding the process of creation, Jung (2011) states that the choice of theme or inspiration that emerges from the author's mind comes from unconscious processes, are produced by the need of creation that is inherent in human nature, namely, the production of both a dream and fantasy, as a work of art, are part of a creative process in any way belong to the artist. Artistic production is considered in analytical psychology as a manifestation of psychic reality, and this reality has the feature of the ineffable.

According to Morin (2000a, 2000b), creativity is very important during teaching, but it is not widely developed at school, on the contrary, school work is done in a piecemeal way, it does not allow the individual to work with a vision of the whole (Piske et al., 2016a, 2016b).

The creative teaching can provide autonomy and self-knowledge. It makes students use their fantasy, imagination and freedom of expression. In addition to a particular method, it is important that the teaching staff instigate students to know themselves and to have autonomy through creative classes.

Include a student is more than just being at school and attend classes. Offer an education that is in accordance with gifted needs is a challenge that has not yet been reached. In the case of gifted students, differentiated teaching occurs during their specialized service, whereas in the regular classroom there are still many limitations, in general, teaching is repetitive and monotonous.

Educational practices are essential and through them these students can feel valued and included in the school context, however, most of the teachers when 
faced with the needs of these children still does not feel prepared to attend these students. Thus, this paper investigates inclusive practices that promote a creative education to gifted students.

Piske, Stoltz \& Machado (2014a, 2014b) point out the need to provide educational practices aimed at working with creativity. Several studies highlight the importance of specialized service for gifted students to work with a creative teaching (Silverman, 1993; Davis \& Rimm, 1994; Renzulli 2004; Gross, 2016, Kane, 2016, Alencar, 2001; Landau, 2002; Pérez, 2004; Piske, 2013a, 2013b, 2013c; Piske, 2016, Piske et al., 2016b, Stoltz, 2016; Freitas \& Negrini, 2008, among others).

However, the number of gifted students who are attended during special programs is very small (Alencar, 1986), for this author, most students with high potential still remain in regular rooms, with limited opportunity to develop their creativity, therefore there is a great loss to our society, because gifted individuals can contribute to important scientific discoveries.

It is a enormous complexity to understand how gifted students think and learn. Developing the potential of gifted students is a complex challenge for a teaching team that has many questions about how to work with these students who are always in search of new discoveries. It is necessary to carry out activities of their interest and enriching curriculum.

Activities that favor the deepening and enrichment of curricular aspects to the students who present giftedness, so that their potentialities are developed, Allowing the gifted student to complete basic education in a shorter time [...] (Brasil, 1995: 48-49).

Inclusive practices for gifted learners are essential if the education of these students is to develop significantly and for the school to attend their needs in each development dimension.

An important factor is that teachers need to work with the development of creativity in their classrooms. Alencar (2001) defines creativity as a natural and inherent resource for every human being, it should be more worked in classrooms, because the school reality points to the inhibition of creative potential during the teaching-learning process, instead of encourage freedom of expression and promote the curiosity of the students with high potential, some schools repress creativity. Alencar (2001: 60) points out:

This precious resource has, however, been severely inhibited by adverse forces present in our culture and which prevent us from developing and realizing our potential to create things. (...) In some schools, excessive preoccupation with order, control and discipline also limits the possibilities for creative expression, contributing to the perception of the student who thinks of school as an often aversive and monotonous place.

Therefore, creativity and imagination are important and constitutive elements of knowledge, and this should not be neglected by education.

It is important to have a teaching that arouses the curiosity and interest of 
these children, otherwise they may have negative attitudes regarding the school. de Souza Fleith (1999: 38) expresses that:

[...] Negative attitudes toward school, as well as a curriculum and educational strategies that do not take into account individual differences regarding interests, learning styles, and abilities, are some of the factors that can negatively interfere in the performance of gifted students.

Morin warns that the model of education, especially, cannot ignore the curiosity of the students, that is, always instigating curiosity and not killing it, as school often does. Thus, it is essential to create means of transmission of knowledge in the service of students' curiosity (Rangel, 2014).

Another important factor put forward by the author is that education should stimulate the full employment of general intelligence, favoring the natural ability of the mind to pose and solve problems; Thus stimulating mind activity, curiosity, and creativity (Morin, 2003).

\section{The Development of Creativity at School}

There are activity tips that try to make each gifted child to express their ideas, to play with other gifted children, to motivate each child to an event analysis, to generate multiple hypotheses about a certain subject, to solve problems, among activities. Alencar \& Fleith (2001: 37) highlight activities that can be performed with gifted children:

- Research activities on topics of student interest;

- Activities that stimulate the students' imagination;

- Activities that allow the student to explore and know different areas of knowledge;

- Activities that lead the student to produce many ideas;

- Activities that lead the student to play with ideas, situations and objects;

- Activities that involve critical analysis of an event;

- Activities that encourage the student to raise questions;

- Activities that lead the student to generate multiple hypotheses;

- Activities that develop in the student the ability to explore consequences for events that may occur in the future;

- Activities that involve the discussion of real world problems;

- Activities that encourage students to define and solve problems.

All these activities can be considered as parameters for the school to take initiatives to include a creative work with gifted child in some areas of knowledge since in many cases this same child needs of psycho-pedagogical support and a work of enrichment curricular happening in the extracurricular activities. For the success of the foregoing for the development of the gifted student, it should not be forgotten that "if pedagogical practice is carried out by human subjects, then there is no way of not recognizing that objectivity, subjectivity, reason and emotion merge, forming a all unique and complex, that does not admit magic formulas to be effective" (Guérios, 2002: 164). Such magic formulas are the pre- 
cepts of pedagogic doing that inhibit creativity and free do. In conclusion, the teachers' action is linked to the way they conceive the school space, as we stated earlier. In this sense, complex thinking is given by the complementary articulations (Morin, 2000) among the constituent elements of the "constitutive mesh of pedagogical practice in the school educational context-student, teacher, circumstances, specific knowledge, pedagogical knowledge" (Guérios, 2002: 174).

In a context of complexity, specialized knowledge about the gifted student will not be given as a fragment, but in a relational and complementary way in order to provide, as Piske, Stoltz, \& Machado (2014a) quoted, educational practices that promote the creative action of Students, especially the gifted student. Perhaps, considering this perspective as a component of the complexity of the educational field (Mindal \& Guérios, 2013), it is possible to minimize the recurrence of problems that generate conflicts in the formation of teachers in Brazilian education.

\section{Conclusion}

Morin \& Jung can contribute to the education of gifted students emphasizing the importance of self-knowledge of these students in relation to their potentialities and possible limitations.

For Morin and Jung, the teaching staff has a key role in making their students become independent and investigative individuals. So the desire to investigate about the area of interest of the gifted child will depend on how this child is encouraged by their teachers.

Morin $(2003,2007)$ points out that teachers should develop students' critical sense. It is important that teaching staff create means of transmitting knowledge to instigate the students' curiosity (Piske et al. 2016a, 2016b).

According to Jung $(1978,1983,2007)$, it is important that teachers have the ability to influence their students to develop their psyche. And because of its powerful influence on the individuation of the child, it is important that the teacher recognize the individuality of each of his students and favor the balanced development of such individuality (Hall \& Nordby, 1993).

Advancement during the teaching-learning process does not depend exclusively on the method, but also on making the child aware that he/she can develop individually within a collective education. In the case of the gifted child, the intervention of the teaching staff is fundamental to develop their high abilities through the development of their creativity in the interaction with their peers. Thus, in this process, we must also re-think the role of the teacher, which for Morin needs to undergo a "transformation" (Rangel, 2014).

\section{References}

Alencar, E. M. L. S. (1986). Psicologia e educação do superdotado. São Paulo: EPU.

Alencar, E. M. L. S. (2001). Criatividade e educação de superdotados. Petrópolis, RJ: Vozes.

Alencar, E. M. L. S., \& Fleith, D. S. (2001). Superdotação: Determinantes, educação e 
ajustamento. São Paulo: EPU.

Brasil (1995). Diretrizes gerais para o atendimento educacional aos alunos portadores de altas habilidades/superdotação. MEC/UNESCO-Serie Diretrizes, Vol. 10.

Brasil (2001). Saberes e práticas da inclusão. Desenvolvendo competências para o atendimento às necessidades educacionais de alunos com altas habilidades/superdotação (Vol. 7). Brasília: SEESP/MEC.

Davis, G. A., \& Rimm, S. B. (1994). Education of the Gifted and Talented (3rd ed.). Boston, MA: Allyn and Bacon.

de Souza Fleith, D. (1999). Psicologia e Educação do Superdotado: definição, sistema de identificação e modelo de estimulação. Cadernos de Psicologia da SBP, Ribeirão Preto, 5, 37-50.

Freitas, S. N., \& Negrini, T. (2008). A identificação e a inclusão de alunos com características de altas habilidades/superdotação: Discussões pertinentes. Revista Educação Especial, Santa Maria, No. 32, p. 273-284. http://www.ufsm.br/revistaeducacaoespecial

Gross, M. U. M. (2016). Developing Programs for Gifted and Talented Students. In F. H. R. Piske, T. Stoltz, J. M. Machado, \& S. Bahia (Orgs.), Altas habilidades/Superdotação (AH/SD) e Criatividade: Identificação e Atendimento [Giftedness and Creativity: Identification and Specialized Service] (pp. 61-75). Curitiba: Juruá.

Guérios, E. (2002). Espaços oficiais e intersticiais da formação docente: Histórias de um grupo de professores na área de Ciências e Matemática. Tese (Doutorado em Educação), Campinas: Faculdade de Educação, Universidade Estadual de Campinas.

Guérios, E. (2005). Espaços intersticiais na formação docente: Indicativos para a formação continuada de professores que ensinam matemática. In Cultura, formação e desenvolvimento profissional de professores que ensinam matemática (pp. 128-151). São Paulo: Musa.

Hall, C. S., \& Nordby, V. J. (1993). Introdução à obra Junguiana (122 p). São Paulo: Cultrix.

Jung, C. G. (1921). Psychological Types. The Collected Works of C. G. Jung, Vol. 6, Bollingen Series XX.

Jung, C. G. (1947). On the Nature of the Psyche. London: Ark Paperbacks.

Jung, C. G. (1948). The Phenomenology of the Spirit in Fairy Tales. The Archetypes and the Collective Unconscious, 9(Part 1), 207-254.

Jung, C. G. (1953). Collected Works (Vol. 12). Psychology and Alchemy.

Jung, C. G. (1978). Jung Speaking. London: Thames \& Hudson.

Jung, C. G. (1983). O Desenvolvimento da Personalidade. Petrópolis: Vozes.

Jung, C. G. (2007). Psicologia do Inconsciente. Petrópolis, Vozes.

Jung, C. G. (2011). O Espírito na Arte e Na Ciência. O.C. Vol. 15. Petrópolis, Rio de Janeiro. Vozes, $4^{\circ}$ edição.

Kane, M. (2016). Gifted Learning Communities: Effective Teachers at Work. In F. H. R. Piske, T. Stoltz, J. M. Machado, \& S. Bahia (Orgs.), Altas habilidades/Superdotação (AH/SD) e Criatividade: Identificação e Atendimento /Giftedness and Creativity: Identification and Specialized Service] (pp. 77-94). Curitiba: Juruá.

Landau, E. (2002). A coragem de ser superdotado. São Paulo: A\&C.

Mindal, C. B., \& Guérios, E. (2013). Formação de professores em instituições públicas de ensino superior no Brasil: diversidade de problemas, impasses, dilemas e pontos de tensão. Educar em Revista, No. 50, 21-33.

https://doi.org/10.1590/s0104-40602013000400003 
Morin, E. (1977). O Método I: A Natureza da Natureza (2nd ed., 363 p). Lisboa: Publicações Europa América.

Morin, E. (1979). O enigma do homem: Para uma nova antropologia (2nd ed., 227 p). C. F., Rio de Janeiro: Zahar Editores.

Morin, E. (1980). La méthode 2: La vie de la vié. Paris: Suil.

Morin, E. (1996). O problema epistemológico da complexidade. Lisboa: Europa-América.

Morin, E. (2000a). Les sept savoirs nécessaires à l'éducation du futur. Paris: Seuil.

Morin, E. (2000b). Os sete saberes necessários à educação do futuro (115 p). São Paulo: Cortez; Brasília; DF: Unesco.

Morin, E. (2003). A cabeça bem feita: Repensar a reforma, reformar o pensamento (121 p). Rio de Janeiro: Bertrand Brasil.

Morin, E. (2007). Introdução ao pensamento complexo. Porto Alegre: Sulina.

Morin, E. (2014). Ciência com Consciência (2nd ed.). Rio de Janeiro: Bertrand Brasil, 350 p.

Pérez, S. G. P. B. (2004). Gasparzinho vai à escola: Um estudo sobre as características do aluno com altas habilidades produtivo-criativo. 230 f. Dissertação (Mestrado em Educação), Porto Alegre: Faculdade de Educação, Pontifícia Universidade Católica do Rio Grande do Sul.

Piske, F. H. R. (2013a). O desenvolvimento socioemocional de alunos com altas habilidades/superdotação (AH/SD) no contexto escolar: contribuições a partir de Vygotsky (166 p). Dissertação (Mestrado em Educação), Curitiba: Universidade Federal do Paraná.

Piske, F. H. R. (2013b). A Importância da formação docente para a Inclusão de alunos superdotados. In XI Congresso Nacional de Educação EDUCERE-Formação docente e sustentabilidade: Um olhar transdisciplinar. II Seminário Internacional de Representações Sociais, Educação-SIRSSE. IV Seminário Internacional sobre Profissionalização docente-SIPD, Curitiba.

Piske, F. H. R. (2013c). Criatividade no Processo de Aprendizagem de Superdotados. In III Seminário Internacional de Educação de Pinhais, Pinhais.

Piske, F. H. R. (2016). Alunos com Altas Habilidades/Superdotação (AH/SD): Como identificá-los? In F. H. R. Piske, T. Stoltz, J. M. Machado, \& S. Bahia (Orgs.), Altas Habilidades /Superdotação (AH/SD) e Criatividade: Identificação e Atendimento [Giftedness and Creativity: Identification and Specialized Service] (pp. 249-260). Curitiba: Juruá.

Piske, F. H. R., Stoltz, T., \& Machado, J. (2014a). Creative Education for Gifted Children. Creative Education, 5, 347-352.

http://www.scirp.org/journal/PaperInformation.aspx?PaperID=45206

Piske, F. H. R., Stoltz, T., \& Machado, J. (2014b). Creative Educational Practices for Inclusion of Gifted Children. Creative Education, 5, 803-808.

http://www.scirp.org/journal/PaperInformation.aspx?PaperID=46997

Piske, F. H. R., Stoltz, T., Guérios, E., \& Freitas, S. P. (2016a). Creativity and Complex Thoughts of Gifted Students from Contributions of Edgar Morin and Rudolf Steiner. Creative Education, 7, 2268-2278. http://file.scirp.org/pdf/CE_2016092716142766.pdf

Piske, F. H. R., Stoltz, T., Vestena, C. L. B., Freitas, S. P., Valentim, B. F. B., Oliveira, C. S., Barby, A. A. O. M., \& Lopes, C. L. (2016b). Barriers to Creativity, Identification and Inclusion of Gifted Student. Creative Education, 7, 1899-1905.

http://file.scirp.org/pdf/CE_2016082517133903.pdf

Rangel, A (2014). Últimas de Educação 360. O Globo. 
http://oglobo.globo.com/sociedade/educacao/educacao-360/a-educacao-nao-pode-igno $\underline{\text { rar-curiosidade-das-criancas-diz-edgar-morin-13631748 }}$

Renzulli, J. S. (2004). O que é esta coisa chamada superdotação, e como a desenvolvemos? Uma retrospectiva de vinte e cinco anos. Educação, 27, 75-131.

Silverman, L. K. (1993). Counseling Needs and Programs for the Gifted. In K. A. Heller, F. J. Mönks, \& A. H. Passow (Eds.), International Handbook of Research and Development of Giftedness and Talent (pp. 631-647). Oxford: Pergamon.

Stoltz, T (2016). Imaginação e criatividade na educação: A necessidade de outro olhar. In F. H. R. Piske, T. Stoltz, J. M. Machado, \& S. Bahia (Orgs), Altas Habilidades/Superdotação (AH/SD) e Criatividade: Identificação e Atendimento [Giftedness and Creativity: Identification and Specialized Service] (pp. 249-260). Curitiba: Juruá.

Submit or recommend next manuscript to SCIRP and we will provide best service for you:

Accepting pre-submission inquiries through Email, Facebook, LinkedIn, Twitter, etc. A wide selection of journals (inclusive of 9 subjects, more than 200 journals)

Providing 24-hour high-quality service

User-friendly online submission system

Fair and swift peer-review system

Efficient typesetting and proofreading procedure

Display of the result of downloads and visits, as well as the number of cited articles

Maximum dissemination of your research work

Submit your manuscript at: http://papersubmission.scirp.org/

Or contact ce@scirp.org 